\title{
Healthy Lifestyle Education from Halal Nutraceutical Concept
}

\author{
Abdul Aziz Mohamad, ${ }^{1 *}$ Ahmad Syukran Baharuddin, ${ }^{1}$ Aminuddin Ruskam ${ }^{1}$ \\ ${ }^{1}$ Faculty of Islamic Civilisation, Universiti Teknologi Malaysia, 81310 UTM Johor Bahru, Malaysia \\ *Corresponding author: abuumar@singnet.com.sg
}

\section{Article history}

Received: 2017-04-23

Received in revised form: $2017-10-15$

Accepted: $2017-10-17$

\begin{abstract}
The world is witnessing a return to what is natural, both environmentally and back to fitrah, our innate nature. This does not apply to food, and cosmetic sector only, but also the health and nutraceutical sectors. One of the evidences is the fastest growing sectors in the global personal care market and nutraceutical market as dictated by consumer lifestyle and awareness. This article aims to explore on the healthy lifestyle education contained in nutraceutical concept based on Islamic perspectives. This study used document analysis on primary and secondary documents as methodological approach. This study found that Arab-Islamic medicine or Greco-Arab refers to medicine developed in the Golden Age of the Islamic Civilization. It is extended from Spain in the west to Central Asia and India in the East. 'Prophetic Medicine' although popular amongst the masses of Muslims because of its doctrinal and theological contents was considered by most Muslim historians and physicians as distinct from scientific and analytical Islamic Medicine. Medicine of the Prophet is a combination of religious and medical information, providing advice and guidance on the two aims of medicine. First the preservation of health and second the restoration of health based on the Qur'anic guidance and the Prophetic traditions.
\end{abstract}

Keywords: Halal Nutraceutical, Healthy life education, Medicine of the Prophet. 


\subsection{INTRODUCTION}

Nutraceutical and functional foods provide means to address the increasing burden on the health care system by promoting health prevention rather than treatment. Herbal medicine has been used worldwide as traditional medicines for thousands of years to treat various forms of diseases including cancer. Chemoprevention, a novel approach for controlling cancer, involves the use of specific natural products or synthetic chemical agents to reverse suppress or prevent premalignancy before the development of invasive cancer (Zaid et al., 2010). Several natural products, such as, grains, nuts, fruits, vegetables and medicinal plants confer protective effects against wide range of cancers. Since diet has an important role in the body health, dietary chemoprevention received attention in the Arab-Islamic treatment of diseases including cancer (Zaid et al., 2010).

\subsection{THE DEFINITION OF ISLAMIC MEDICINE}

Islamic Medicine in its true context, can thus be defined as a body of knowledge of Medicine that was inherited by the Muslims in the early phase of Islamic History (40-247 AH/661 -861 AD) from mostly Greek sources, but to which became added medical knowledge from, Persia, Syria, India and Byzantine. This knowledge was not only to become translated into Arabic, the literary and scientific lingua franca of the time, but was to be expounded, assimilated, exhaustively added to and subsequently codified, and 'Islamised'.

Medical teachings were inherited mainly from the Greeks. At the same time, in India, Egypt, China and elsewhere, Islam met medical teachings of those civilizations and incorporated much from their traditions. Ibn Qayyim is aware of all this, but considers it secondary to his theme. This become apparent at the outset of his work, where reference to the Qur'anic description of 'these in whose hearts sickness' is intended to show a difference division of illness and medicine: that of the body and the heart (Penelope, 1998). The Physicians of the times both Muslim and Non-Muslim were then to add to this, their own observations and experimentation and convert it into a flourishing and practical science, thus helping in not only in curing the ailments of the masses, but increasing their standards of health. The effects of its domineering influence extending not only in the vast stretches of the Islamic lands, but also in all adjoining nations including Europe, Asia, China, and the Far East. The span was measurable not only for few centuries, but also perhaps for an entire millennium, 610 to 1610 AD (F. Nagamia, 2003). During which time, Europe and rest of the extant civilized nations of the world were in grips of the 'dark ages'. It also to set the standards of hygiene, and preventative medicine and thus was responsible for the improvement of the general health of the masses. It was to hold sway until decadence finally set in, concomitant with the political decline of the Islamic nation. With the advent of Renaissance in Europe, at the beginning of the 17 th Century $\mathrm{AD}$, it was finally challenged by the new and emerging science of modern medicine, which was to finally replace it in most of the countries, including the countries of its birth! (F. Nagamia, 2003).

Nutraceuticals is term coined in 1979 by Stephen DeFelice (1992). According to Defelice, it is defined "as a food or parts of food, that provide medical or health benefits, including the prevention and treatment of disease." Subsequently, several other terms (medical food, functional food and nutritional supplements) were used. Nutraceutical may range from isolated nutrients, dietary supplements and diets to genetically engineered "designer" foods herbal products, and processed products, such as cereals, soups, and beverages. The increasing interest 
in Nutraceuticals reflects the fact that consumers hear about epidemiological studies indicating that a specific diet or component of diet is associated with a lower risk for a certain disease $(\mathrm{H}$. K. Biesalski, 2001).

Nutraceutical usually refer to healthcare product formulated in pharmaceutical dosage forms like capsules or tablets and carry a limited health claim. They are produced under Good Manufacturer Practices and are currently used as evidence based on healthcare products providing protection against chronic disease conditions or having physiological benefits. Examples are flavonoid antioxidants from various herbs example (Misai kucing, Pengaga), betacarotene from palm oil, anthocyanins from Berries etc. Many botanical and herbal extracts such as lingzhi, tongkat Ali, ginger, kunyit, garlic etc. have been developed as nutraceuticals (Zhari Ismail \& Abdul Halim Ehsan, 2008).

\title{
3.0 Nutraceutical based on the Holy Qur'an
}

Allah said in surah al-Rahman:12 وَالنَّخْلُ ذَاتُ الأُّكْمَاحِ (and date palms producing Akmam.)

Allah mentioned the date tree here specifically because of its benefit, both fresh and dry. Ibn Jurayj reported that Ibn 'Abbas said said Al-Akmam, means sheathed fruit stalks. Similar was said by more than one of the scholars of Tafsir, it refers to the stalks that the seeds grow in to become a cluster of dates, unripe green dates then they ripen and ripen more.

Dates are mentioned in twenty places in the Quran. Prophet (PBUH) is reported to have said: "if anyone of you is fasting, let him break his fast with dates. In case he does not have them, then with water. Verily water is a purifier" (Ibn Qayyim, 2003).

\subsection{Rayhan or Myrtle}

Allah said, وَالْحَبُّ ذُو الْعَصْفِ وَالرَّْْحَانُ (And also corn, with (its) 'Asf, and Rayhan.) 'Ali bin Abi Talhah said that Ibn 'Abbas said that in,

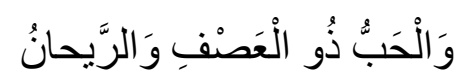

\begin{abstract}
(And also corn, with (its) 'Asf), 'Asf means straw." Al-'Awfi reported from Ibn 'Abbas, 'Asf refers to green leaves cut from the stem, so it is called 'Asf when it dries out.' Similarly, Qatadah, AdDabhak and Abu Malik said that 'Asf means straw. Ibn 'Abbas, Mujabid and others said that rayhan means leaves, while Al-Hasan said that it means sweet-scented plants. 'Ali bin Abi Talhah reported that Ibn 'Abbas said that rayhan means green leaves.
\end{abstract}

The meanings here, and Allah knows best, are the various crops that produce straw, such as wheat and barley, and rayhan are the leaves that grow on the stems. (surah al-Rahman : 12) (Ibnu Kathir, 2003)

Muslim narrated that the Prophet (Pbuh.) said:

Whoever was presented with Rayhan should not refuse it, because it is easy to wear and has good scent.

Every plant that has good scent is called Rayhan. Therefore, every area gives a certain plant that name. For instance, the people to the west, as well as, the Arabs call the aromatic plants Rayban. The people in Iraq and Sham call the Hibk (a type of mint) a Rayban. 
Rayhan or myrtle is cold in the first degree and dry in the second degree. Yet, it is a compound of several qualities, most of which consist of earthly cold essence. Myrtle also consists of a soft hot substance. Myrtle dries the head nicely and is effective as a constipating agent. Myrtle prevents bile diarrhea hot and wet vapor when one smells its scent. Its scent also brings relief to the heart and prevents various ailments, especially when the plant is spread around the house (Ibn Qayyim, 2003). Myrtle also heals the tumors that occur in the two ureters when it is coated on them. When fresh myrtle leaves are ground and blended with vinegar and placed on the head, they will stop nose bleeding. When dried myrtle leaves are crushed and the powder is sprinkled on wet ulcers it will heal them and will heal spots and the ulcers on the hands and feet.

When myrtle is used to rub the body it eliminates sweat, dries the excess wetness and dissipates underarm odour. When one sits in the water that myrtle was cooked in, it will help against infections on the buttocks and vagina and will heal weak joints and broken bones, when it is poured on the wound (Ibn Qayyim, 2003). Also, myrtle helps eliminate dandruff and the wet ulcers and the spots that appear on the head. It also helps the hair against falling and gives it a black color. When myrtle leaves are ground with a little water and then blended with some oil or rose grease and then used as a bandage, it will be suitable against fresh (or humid) ulcers, canker sores, erysipelas (skin infection), acute tumours, urticaria (hives) and haemorrhoids (al-'Awdat, an-Nabatat al-Tibbiyah) in (Yusuf Ahmad, 2010).

According to Ibn Qayyim, (2003) myrtle seeds also help against hemoptysis (spiting up blood) of the chest and lungs. It also coats the stomach and does not harm the chest or the stomach and cleanses them. It also helps against diarrhoea and coughing, and this is a special quality for myrtle that is rarely found in other medications. Myrtle seeds also help urine production and heal (bladder) infections, spider bites and scorpion stings. Using myrtle roots to clean between the teeth is harmful, though. The seeds of Persian myrtle relieve diarrhoea of the bile, stomach, strengthen the heart and help against black bile ailments.

\subsection{Figs and Olive Oil}

The holy Quran mentions many plants as well as animal products among the foods Muslims can enjoy and benefit from their nutritional and health values. Among some of the foods mentioned in the holy Quran and Hadis by the Prophet (PBUH) are grapes, citrus, melon, squash, Figs dates, honey, olive oil, and black seeds.

Figs are a top source of fibre, as well as potassium and vitamin B6. Fibre results in bulkier stools, which lessen the incidence of constipation, hemorrhoids and colon cancer. Melon was among one of the fruits most often eaten by the Prophet. He recommended the use of olive oil, by a statement "Eat olive oil and massage it over your bodies since it is a holy (Mubarak) tree" (Narrated by Ahmad and Al-Tirmidhi) (Zaid et al.,2010).

Further mentioned of fig in Al-Quran

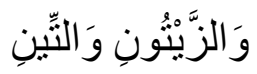

Allah has sworn by the Tin and the Zaitun in the Holy Quran because of its tremendous benefits and uses.

Mujahid said, "It is this fig that you have." 
By Az-Zaytun. Ka`b Al-Ahbar, Qatadah, Ibn Zayd and others have said, "It is the Masjid of Jerusalem (Bayt Al-Maqdis)." Mujahid and 'Ikrimah said, "It is this olive which you press (to extract the oil)."

The mentioned of fig and olive in al-Quran signifies the importance it has in human life and as one of the chosen fruits by Allah swt for human consumption that provides both nutrition and tastes delicious. In this manner Allah swears in the beginning of the verse of surah at-Tin, by the fig and olive shows beside the locality of the trees - that accordingly to Muhammad Asad, the fig and the olive symbolize, in this context, the lands in which these trees predominate: ie.,the countries bordering on the eastern part of the Mediterranean, especially Palestine and Syria and on the other which emphasis the important of the place near Mount Sinai, stresses specifically the apostleship of Moses, in as much as the religious law valid before, and up to, the advent of Muhammad (Pbuh) (M.Asad,1980) but most pertinent is the nature of food for mankind that is easily accessible and healthy.

According to al-Zuhayli, (2001) Allah begins the verse by swearing upon the fruit known as al-Tin, which is the daily dietary food for the Arabs and upon the fruit of al-Zaytun for its rich mineral oil content. The fruit al-Tin also known as figs is a preferable source of food because of its palatable nature and is easily digested and it does not stress the stomach. It too is beneficial to reduce high body temperature. Further he reiterated, it cleanses the kidney, removes gall-stone and refreshes the body. Al-Tin is the best of fruits as it is considered as a nature cure to our sickness and it expiates disease from our body naturally.

\subsection{Miracles of Olive oil In Nutraceutical}

For the first time in history, 16 of the most eminent doctors in the world met in the city of Rome on $21^{\text {st }}$ April 1997, to issue their joint recommendation and decisions on the topic of olive oil and the Mediterranean diet. These scientists issued their recommendations in statement of more than 30 pages, in which they discussed the latest scientific research on olive and the Mediterranean diet research. In their statement, they confirmed that consuming olive contributes to protecting against coronary artery diseases, high cholesterol levels in the blood, high blood pressure, diabetes and obesity; it also protects against some cancers (Yusuf Ahmad, 2010).

Until 1986, no American or European researchers paid attention to olive until Doctor Grundy presented his research in 1985, in which he proved that olive oil lowers cholesterol levels, after which many studies came one after another, focusing on the benefits of olive oil, and discovering day after day more of the secrets of this blessed oil comes from a blessed tree. The messenger of Allah, PBUH, said: "Eat olive and rub it on your skin, for it comes from a blessed tree."(Narrated by Ahmad and Al-Tirmidhi, who said it is a Hasan sahih Hadis.)

According to Yusof Ahmad (2010), how can it not be blessed, when Allah, the Exalted, has sworn by its land, in the verses in which He says:

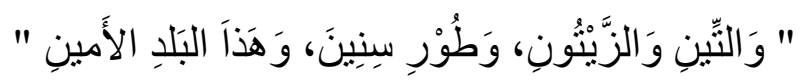

"By the fig, and the olive. By Mount Sinai, and by this city of security (Makkab)" (At-Teen, 95:1-3

How can it not be blessed when Allah has likened His light to the light that emanates from its oil, when He said: 


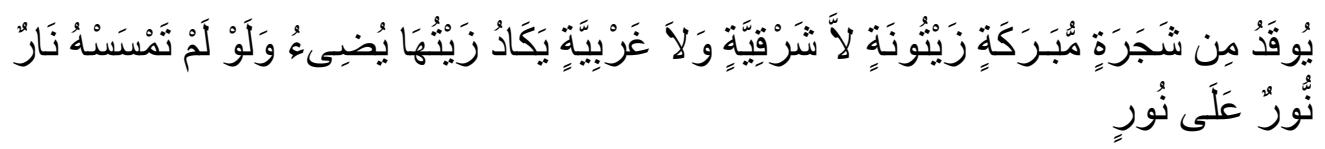

Allah is the Light of the heavens and the earth. The parable of His Light is as a niche and within it a lamp: the lamp is in a glass, the glass as it were a star Durriyyun, lit from a blessed tree, an olive, neither of the east nor of the west, whose oil would almost glow forth, though no fire touched it. Light upon Light! (surah An-Nur, 24:35)

So the tree is blessed and the oil is blessed, but many people are unaware of that. Olive oil is a gift from heaven to man. The ancients were aware of some benefits, and a few years ago modern science began to realize some of its benefits. We have come to know recently that olive oil protects against the disease of modern age, such as heart attacks, and it delays hardening of the arteries. The myth which said that olive oil increases cholesterol in the blood has now been refuted; the spectre that scared many away been laid to rest. Modern science has discovered that olive oil is the enemy of cholesterol, and fights it wherever it is in the human body (Yusuf Ahmad, 2010).

\subsection{A Diet Rich in Olive Oil}

In research undertaken by Dr. Albo Ferraro in the University of Naples in Italy, and published in the Archives of Internal Medicine on $27^{\text {th }}$ March 2000, he studied 23 patients with high blood pressure, on average 104/165, and who were taking medicine for that. He put the first half of the group on a diet rich in virgin oil, and put the second group on a diet rich in sunflower oil. After six months he switched the diets of the two groups for a further six months. The results of the study showed a lowering of blood pressure by seven points in those who were consuming olive oil, whereas there was managed to reduce their doses of blood pressure medicines by half, under medical supervision on course. Eight of the patients who had slightly high blood pressure no longer needed the medicines during the study, whereas no noticeable change was seen in the doses of medicine for the patients whose food was rich in sunflower oil. It must be noted that it is essential to follow medical advice, and it should not be understand from this that patients with high blood pressure can consume olive oil and stop their medicines. This is very important, and it is essential to have regular checkups with a doctor (Yusuf Ahmad, 2010).

\subsection{Anti-Cancer Activity of Olive Oil}

Anti-cancer activity of olive oil is associated with its high content of antioxidants. In addition the anticancer effects are attributed agents (such as squalene and terpenoids).In vito investigations have found that olive oil phenols are potent antioxidants, which may provide potential chemoprotective properties. Hydroxytyrosol was found to induce apoptosis, to arrest cell cycle progression at the G1 phase, to protect cells from hydrogen peroxide-induced damage. In addition, DNA from peroxynitric-induced damage. The substitution of olive oil in the Mediterranean diet may explain its apparent cancer chemo preventive effects (Cancer Treatment by Greco-Arab and Islamic Herbal Medicine, in Zaid et al., 2010).

\subsection{Black Seeds (Nigella Sativa)}

Nigella sativa is one the most revered medicinal seeds in history. In civilizations around the world, herbal spice Nigella Sativa referred to as Habbat-el-barakah (literally seeds of blessing in Arabic), Kalonji (Hindi), Kezah (Hebrew), Sijah Daneh (Persian) and in English called Black Caraway. 
The famous Greek physician Dioscorides (40-90 AC) used black cumin seeds to treat headaches and toothaches. Nigella sativa seeds and oil extracts has been used widely for centuries to treat interruptions in the respiratory system, stomach, kidney and liver function, circulatory, the immune system as well as cancer. In Islam, it is regarded as one of the greatest forms of healing medicine available (Zohary D, Hopf M., ${ }^{\text {rd }}$ Ed. Oxford University Press, 2007)

The Black Seed has many benefits, as indicated by the Prophet's statement:

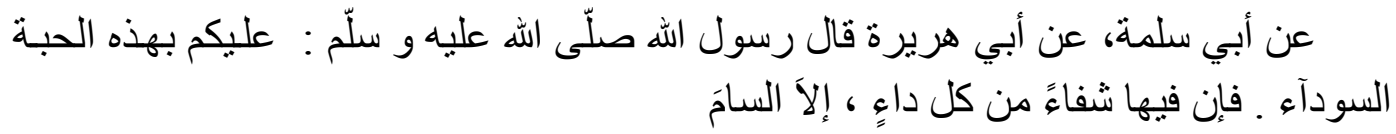

Use the Black Seed, because it contains a cure for every type of ailment, except death. (AtTirmidhi:1964, \& Abmad: 6986)

"It is a cure for every type of disease." This statement is just like what Allah said :

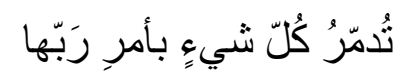

"Destroying everything by the command of its Lord." (46:25)

Its means destroys everything that is prone to destruction. (Ibn Qayyim, 2003)

Avicenna refers to black seed in his Canon of Medicine, as the seed that stimulates the body's energy and helps recovery from fatigue and dispiritedness. In the Unani Tibb system of medicine, seeds are regarded as a valuable remedy for a number of diseases. The seed's oil has been used to treat skin conditions such as eczema and boils and to treat cold symptoms. The modern research confers that Nigella sativa seeds ethanol extract possess antitumor activity in mice tumor primary cells Nigella sativa seeds extracts contains amino acids, proteins, carbohydrates, alkaloids, saponins, fixed and volatile oils, and many others (The Open Nutraceutical Journal, 2010).

The Black Seed helps against all types of cold ailments. Also, it helps introduce the effective ingredients of cold medications to the areas affected by hot and dry ailments, as it helps absorb the medicine quickly when taken in small dosage. The author of Canon of Medicine and other people stated that saffron blended with camphor has similar effects, because saffron helps the camphor reach the affected area quickly. There several types plants that have similar effects as saffron. It is possible that the hot substance benefits in cases of hot diseases. For instance, the Anzarut, which is a type eyeliner, is mixed with other remedies for Ophthalmia, conjunctivitis and so forth. Ophthalmia is a hot tumour as the doctors agree. Also, sulphur is remedy for hot mange. When the Black Seed is ground, blended with honey and drunk with some warm water, it will dissolve the stones that appear in the kidney and the prostate, and it also diuretic, It increase the flow during menstruation and the production of milk if it is drunk for several days. When it is heated with vinegar and placed on the stomach, it will eliminate helminthes (worms). When it is blended with wet or cooked colorynth water, it is more effective in removing helminthes (worms). It also clears up, decomposes and relieves cold symptoms when it is ground in a rag and inhaled through the nose on a regular basis until the ailment is cured. Black seed oil helps against snakebites, haemorrhoids and spots. When around 25 grams of it drunk with water it will help against gasping and hard breathing (Ibn Qayyim, 2003). 


\subsection{Dry Dates / Tamr}

In the Sahih it is narrated that the prophet (pbuh) said:

"Whoever ate seven dates in the morning from the area of "Aaliyah will not be harmed by poison or magic the rest of that day."

He also said:

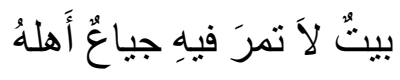

"The people of a house where there are no dates are hungry"

Also the prophet (Pbuh) ate dried dates with butter, with bread and alone. Tamr is hot in the second degree and either wet or dry in the second degree. Dried dates are a fruit, a type of food, a cure, a drink and a sweet. Dried dates strengthen the liver, relax the bowels increase semen production, especially when taken with pine and relief sore throat. As for those who are used to eating dried dates, such as the residents of cold areas, dried dates cause clogs, harm the teeth and cause headaches, unless they are eaten with almonds and poppy.

Dried dates are among the most nutritious fruits, their essence is hot and wet. Especially when one eats dates in the beginning of the day, they help kill worms. Although dried dates are hot, yet they have the strength of an antidote against worm, killing or at least decreasing their numbers, especially when dried dates are taken frequently on an empty stomach (Ibn Qayyim, 2003).

\subsection{Honey (Asal)}

The benefits of honey have already been listed. Said Ibn Juraij: al-Zuhri said: Take honey, for it is good for the memory. The best sort is pure, the white, the least sharp, and the sweetest. That which is gathered from beehives as the excellence of its quality is in accordance with the bees' source of nectar (Ibn Qayyim, 2003).

In the two books of the Sabih it is related, from the hadith of Abu al-Mutawakkal, from Abu Said al-Khudri: A man came to the prophet (Pbuh) and said: "My brother is suffering in his belly, (he has diarrhoea)". He replied: "Give him honey to drink". "The man went away but returned saying: "I have dosed him, but it has done no good" (in another version), It has only increased his diarrhoea. This took place two or three times, and the prophet said each time: 'Give him honey.' On the third or fourth occasion, he said: 'God has spoken the truth, but your brother's belly has lied' (al-Bukhari, Tibb,no.5684) (Johnstone, Penelope, 1998).

Honey contains great benefits: it removes the impurities from the veins, the intestines and elsewhere, and it dissolves the moistures when it is eaten or used as an embrocation. It is beneficial for old people and those with excess phlegm, and those of cold and moist temparent; it is nutritious and is an emollient to the constitution. It preserves the strength of ointments and anything of which it is an ingredient; it dispels the unpleasant properties of medicines; it cleanses the liver and the chest; it is diuretic; and it is appropriate for a cough arising from the phlegm. When drunk hot water with rose oil, it is beneficial against the bite of poisonous vermin or the effects of opium. Alone and mixed with water it is beneficial against the bite of a mad dog or the results of eating deadly fungus (futur). When fresh meat is put in honey, it preserves its freshness for three months; the same applies to squash, cucumber, gourd and aubergine. Honey preserves most fruit for six months. It can also preserve dead bodies. It is known as the 'trustworthy preserver' (Penelope, 1998). 
Further, when honey is applied to someone that is infected with lice, it will kill both the lice and eggs. Honey will in addition add softness and beauty to the hair while allowing it to grow longer. When honey is applied to the eye as a Kubl, it will strengthen weak eyesight.

Honey in addition whitens the teeth, preserves their health and the health of the gums, and opens the orifice of the veins along with causing the flow of menstruation. Furthermore, licking honey on an empty stomach will help the body get rid of mucus and phlegm. It cleanses the stomach and rids it of harmful substances or mixtures, heats the stomach mildly and opens up the pores. Honey has similar effects on the kidneys, the prostate and the liver. Furthermore, honey is the least harmful sweet substance for congesting the liver and kidneys (Abd El-Aziz, 2003).

According to Ibnu Qayyim (1998) honey is guaranteed to be free of side effects and can do very little damage. It can accidentally harm those of a bilious temperament, but this can be averted by the use of vinegar or something similar, whereupon it is again of great benefit. It is to be classed among both foods and medicines, and among drinks; it is regarded as a sweetmeat, and as an embrocation, and as the delights of life. Nothing of this kind has been created for us which is more excellent, nor even similar or near to it in quality. The Ancient placed all their confidence in it. Hardly any of the books of the Ancients mention sugar, nor did know it for it is of fairly recent date. The prophet (Pbuh) used to drink honey with water, on an empty stomach; herein lies a most notable secret for the preservation of health that is only to be grasped by the astute and the discerning.

In the Sunan Ibn Maja (marfu'), from the hadith of Abu Hurayrah it says: "If someone takes an electuary on three mornings every month, he will not be touched by a major affliction"(Ibn Maja, Tibb, 7). Another hadith says: "You must use the two sources of healing, honey and the Qur'an". (Ibn Maja, Tibb, 7.) For it combines human and divine medicine, the medicine of the body and of the spirit, the earthly and the heavenly remedy. Bearing these unique properties of honey in mind we see why the prophet (Pbuh) prescribed it. The man's diarrhoea was caused by indigestion which afflicted him because of repletion, so he ordered him to drink honey to repel the superfluities congested in both the stomach and intestines, as honey can cleanses and repel superfluities. His stomach had become afflicted by viscel humors, which through their stickiness prevented the food from settling down. The stomach has a fibrous surface like that of a towel, and when the viscid humors attach themselves to it, they corrupt both the stomach and the food. The appropriate medication is that which will cleanse it of these humors. Now honey is a cleanser and is one of the best ways of treating this complaint, especially when it is mixed with hot water (Penelope, 1998).

Ibn Qayyim (1998) described that in giving repeated doses of honey there is an excellent medical concept, namely that the medicine must be of a measure and quantity in accordance with the state of the illness. If insufficient it will not completely eliminate it; and if in excess it will weaken the strength and cause some other harm. When the prophet (Pbuh) ordered the man to give is brother honey, he did not give enough to combat the disease nor attain the objective. Then when the man told him, he knew that the dose given did not reach the required amount. When the request was repeated, the prophet (Pbuh) confirms the repetition of the dose that it would reach the amount required to combat the illness. So when successive doses have been given in accordance with the substance of the disease, the cure is manifest, by God's will 
(decree). Thus carefully calculating the measure and qualities of medicines, and the extent of the power of the illness and the strength of the patient, are among the major rules of Medicine.

The saying of the Prophet (Pbuh): 'God has spoken truly but your brother's belly has lied.' (alBukhari, Tibb,no.5684) confirms that this remedy is useful and that the persistence of the illness is not due to a defect of the medicine in itself, but rather due to the belly's unreliability and the amount of corrupt matter within it. Therefore he ordered a repetition of the dosage according to the quantity of putrid matter (Ibn Qayyim, 2003).

According to Abd El-Azeer, (2003) therefore, when people ignore Prophetic medicine, it is like ignoring the help and guidance of the Qur'an, which is the most effective medicine. Again, when the medicine (the Qur'an and the Prophetic medicine) do not work, it is due to the negativity in the body and soul that are not suitable for accepting the medicine, not because the medicine does not work. All success comes from Allah, wherein is healing for men. Allah said in surah al-Nahl;

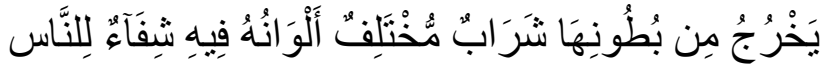

There comes forth from their bellies, a drink of varying colors, wherein is healing for men. (surah alNabl, 16:69)

Meaning, honey, that is white, yellow, red, or of other good colors, depending on the different things that the bees eat (Ibnu Kathir, 2003).

The disagreement revolves around the words "wherein healing for men", if they refer to the drink or the Qur'an? There are two opinions on this matter, the closest to the truth is what Ibn Mas'ud, Ibn Abbas, Al-Hasan, Qatadah, and majority of the scholars stated, that these words refer to the drink (شراب). The ayah (verse) is talking about the drink and not the Qur'an. Adding to this fact, the prophet (Pbuh), said in the previous hadith, "Allah has said the truth," as it is clear in determining that the verse is referring to the drink. Allah knows best.



"In which there is a cure for men"

Meaning there is a cure in honey for diseases that people suffer from. Some of those who spoke about the study of Prophetic medicine said that: if Allah had said, "in which there is the cure for men", then it would be the remedy for all diseases, but He said, "in which there is a cure for men', meaning that it is the right treatment for every "cold" disease, because it is "hot", and a disease should be treated with its opposite (Ibnu Kathir, 2003).

\subsection{The miracle of Vinegar (Khal)}

Muslim narrated in his Sahih that Jabir bin 'Abdullah r.a said, The Messenger of Allah (Pbuh) asked his wife for food and she said that, "I have vinegar". He asked for some of it and started eating it while saying:

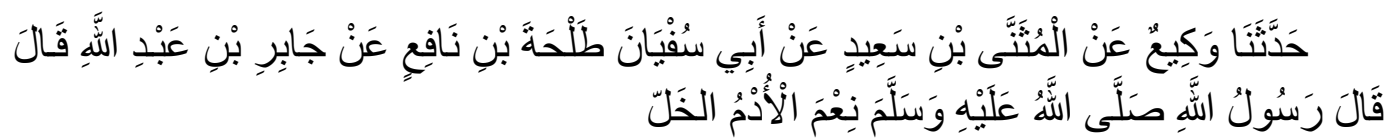




\section{عن جابر بن عبد الله رضي الله عنهما قال: قال رسول الله صلى عليه و سلم : نِعَمَ الإدامُ الخّل}

"What an excellent food is vinegar. (He ate it with bread)

Khal is a substance that is both hot and cold, although coldness is usually more apparent. It is also dry in the third degree and a strong drying agent. Vinegar also soothes the body and softens the nature.

Wine vinegar helps against gastric inflammation and bile and prevents the toxic medications. It also decomposes milk and the blood when coagulated, and helps the spleen, coats the stomach, constipates, quenches the thirst and prevents tumours from occurring. It also helps the digestion process, works against phlegm, softens thick food and softens the consistency of the blood.

When vinegar is drunk with salt, it will help against poisonous mushrooms. When vinegar is sipped, it will dissolve the clogs that occur in the blood in the lower jaw. When one rinses his mouth with warm vinegar, it relieves toothache and strengthens the gingival. Vinegar also helps against a septic finger when it is anointed with it, and also relieves pustules, hot tumours and fire burns. Vinegar is an appetite stimulant, soften the stomach, and favourable for young people and for those who live in warm areas (Ibn Qayyim, 2003).

\subsection{NUTRACEUTICAL THE KEY TO A BETTER LIFE}

The prophet S.A.W used to drink some honey mixed with water on an empty stomach. There is a wonderful secret behind this practice regarding preserving the health. Only those whom enjoy sound comprehension will be able to recognize such a secret (Ibnu Qayyim,2003).

Black seeds were regarded as a medicine for that cures all types of diseases. The Prophet once stated, "The black seed can heal every disease, except death" (at-Tirmidhi: 1964; and Ahmad: 6986).

As stated above, Avicenna had described four approaches to treat cancer, he had also mentioned that:

\footnotetext{
"It (cancer) can be reached by controlling the material (atrabile), improving the diet and reinforcing the involved organ by the known effective medicines, and by using mineral smears like those containing millstone dust and whet-stone dust and from smears taken from a mixture between the stone pounder for aromatics and black head stone moisturized with rose oil and coriander water poured on pounder. And also a dressing with well pounded verjuice is good and useful" (Ibnu Sina, 2013).
}

The Prophet S.A.W said :

"When Allab loves a slave, He helps him observe a diet from the life of this world, just as one puts his patient on a diet from food and drink. Allah puts His believing slave on a diet from the life of the world."

The famous statement that "diet is the top medicine; and the stomach is the home of disease; give each person what he is used to (of food and medicine)," This is not a hadis, according to the scholars of hadis. Rather, it is the words of Harith bin Kaladah, the renowned Arab doctor (Ibnu Qayyim, 2003).

Al-Harith stated that "Diet is the head of medicine". To doctors, observing a diet by healthy people is as harmful as unhealthy eating habits for patients. Consequently, the best type of diet is that observed by those recovering from an illness, because until then, their body organs would 
not have regained their normal strength and wellbeing. In this condition, the digestion process would not be at its normal efficiency while the various organs of the body would still be prone to sickness. At this time unhealthy eating habits might cause the disease to come back stronger than it was before. Know that the Prophet's disallowing 'Ali r.a from eating the hanging clusters of dates while still recuperating from an illness is one of the best preventive measures (Ibn Qayyim, 2003).

\subsection{The Culture of Tahneek in Nutraceutical}

Islam has paid a great of attention to the care of the infant and mother throughout all stages of development. What the United Nations, human rights organizations and World Health Organization have to say cannot with it.

In Islam, care of the infant does not begin at the moment of birth; rather it begins from the time a person first thinks of marriage. The Prophet, Pbuh., enjoined us to choose good husbands and wives. Islam pays a great of attention to the soundness of the offspring and the formation of a strong family, not only from a moral point of view, but also taking into account of a strong family, not only from moral point of view, but also into account physical, hereditary and psychology aspects. This care continues during pregnancy, birth, breastfeeding and the stages of child rearing that follow. One of the manifestations of this care is the Tabneek (chewing a date or something sweet, then putting it into the newborn's mouth and rubbing it into the roof of the mouth with one's finger until it dissolves.) of the new-born (Yusuf Ahmad, 2010).

Al-Bukhari narrated in his Sahih from Asma' binti Abi Bakr, may Allah be pleased with her, that she got pregnant with Abdullah Ibn Zubair in Makkah and gave birth in Quba' She said, Then I brought the child to the messenger of Allah, and placed it(on his lap). Then he asked for a date and chewed it, then he spat into his mouth, and first thing to enter his stomach was the saliva of the Messenger of Allah, (Pbuh). Then he rubbed the inside of his mouth with the date, and then he prayed for him and blessed him" (al-Bukhari, no.5469).

In the two Saheeh it is narrated that Abu Musa, r.a., said,

"A son was born to me and I brought him to the Prophet, Pbuh., and he called him Ibrabim and rubbed the inside of his mouth with a date, and prayed for him, to be blessed, then he gave him back to me"(The narrator added: that was Abu Musa's eldest son) (al-Bukhari, hadis no.,5467).

\subsection{The prophet's guidance on observing a diet as part of the cure}

The most effective way for illness prevention in Islam is healthy diet. Prophet Mohammad, (PBUH) said: "Food is the source of illness; however, the diet program is the source of health"

Avicenna also had discussed the diet effect on cancer progression. In regard of cancer prevention, he said: As to preventing its (cancer) progress, it can be achieved by, improving the diet and reinforcing the involved organ by the effective medications,"

It is well known nowadays that several chemicals are carcinogenic and that obesity is a cause of various diseases including cancer (Zaid et al., 2010).

All types of cures and medicine contain either a certain diet or preventive measures. When one feels ill, he will need to get rid the body from harmful substances and bodily wastes. These three elements are what medicine is all about. There are two types of diet, a diet from what bring 
illness and a diet from what might intensify the illness. The first type of diet is for the healthy and the second type is for those with an illness. When the patient observes a certain diet, the illness will not progress and thus the powers contained in the body will cooperate and collaborate towards ridding the body of the ailment (Ibn Qayyim, 2003).

\subsection{DISCUSSION, RECOMMENDATION AND CONCLUSION}

The concept of Halalaan Toyyiban is in conjunction with WHO guidelines for the assessment of herbal medicines, as indicated in Figure 1. All the steps from obtaining the crude materials, to its preparatory stage then to relaying the information to customer, right to the finished product to its storage stability and down to its quality must prove its efficacy and safety for consumption must be proven, each a quality processes by itself. It is not just physically demanding as it is exhaustive, and industry players such as manufacturers must ensure that quality is not compromised.

The checks and balances to ensure that consumers not only get the best product for their health but it is also cost-effective. In this instance knowledge-based advertisement on the products, its usage, shelf life and benefits disseminated to the public is necessary based on fact and not a fallacious claim.

Halal product has assimilated into Muslim life in more than one way - thus making it more comfortable and reachable to most Muslims day by day. However, most Muslims take the halal logo or assurance at face value, meaning as long as a product carries a halal logo and certified by a competence authority Muslims has no qualm about it. Hence, the product's ingredients need to be inspected and tested for permissibility to meet the halal requirement and standard. Unfortunately, some of the ingredients are unable or difficult to be identified through its source, which can be categorized as shubhah or doubtful. These ingredients should be avoided. Halal Nutraceutical consumer are now starting to question the authenticity and integrity of the Halal nutraceuticals that they consumed, especially that came from the non-Muslim manufacturers and distributors in Singapore.

Figure 1 The Concept of Halalan Toyyiban in Nutraceutical Products

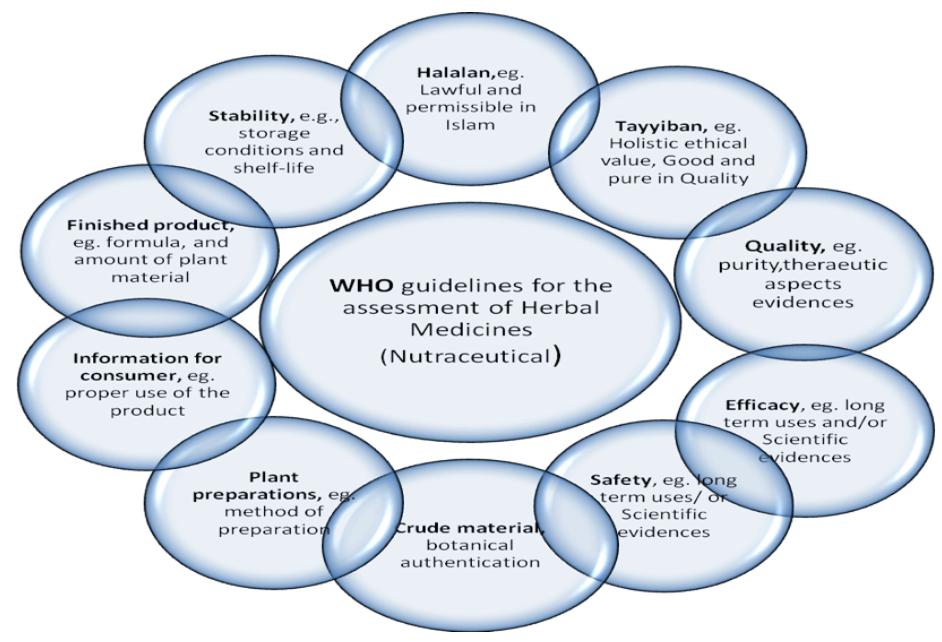

WHO Guidelines for the assessment of Herbal medicines, 1991 


\section{References}

Ahmad Sonhadji Mohammad. (1990). Tafsir al Qur'an Ibnu al Athir, Kuala Lumpur: Pustaka Mizan. 47-48

Al-Qaradawi, Yusuf. (2010). The Lawful and the Prohibited in Islam. Petaling Jaya, Selangor, Malaysia, Islamic Book Trust.10

Al-Qur'an- A summarized version of At-Tabari, Al- Qurtubi. (1995). Dr.Muhammad Muhsin Khan, Islamic University,Al-Madina Al- Munawwara, Riyadh, K.S.A.,Darus-Salam Publications. 66

Attewell, G. (2003). Islamic Medicines: Perspectives on the Greek Legacy in the History of Islamic Medical Traditions in West Asia, In Selin, H. (Ed.). Medicine Across Cultures: History and Practice of Medicine in Non-Western Cultures, pp. 325-350. Dordrecht, The Netherlands: Kluwer Academic Publishers

Avicenna, Avicenna's Medicine. (2013). A New Translation of the 11th century Canon with practical application for Integrative Health Care, translated by Mones Abu-Asab, Hakima Amri and Marc.s Micozzi, Healing Art Press. Toronto, Canada.

Chaudry, M.M. (1994). Is kosher gelatin really halal? Islam Perspectif., XI(1), Riaz, M.N. (2004) Halal Food Production, CRC PRESS, Boca Raton FL.

Dewi Hartaty Suratty. (2012/2013). Halal Certification Strategic Unit, (MUIS), Singapore Halal Directory, Publisher Marshall Cavendish Business Information Pte. Ltd. Singapore.

Fatwa of the State Mufti. (2009). Issues on Halal Product, Brunei Darussalam. Publisher: State Mufti's Office, Prime Minister's Office.

Fischer, Johan. (2011). The Halal Frontier: Muslim Consumers in a Globalized Market. New York: Palgrave Macmillan.

Fischer, Johan. (2016). Islam, Standards, and Technoscience ;In Global Halal Zones published by Routledge, 711 Third Avenue,New York.

Hamarneh, Sami Khalaf. (1973). Al-Biruni's book on Pharmacy and Materia Medica, Historian of Pharmacy, Hamdard National Foundation, Karachi, Pakistan

Hamarneh, Sami Khalaf. (1983). Health Science in Early Islam, Noor Health Foundation \& Zahra Publications ISBN for Volume 1 (E-Book Version): 978-1-919826-84-4

Hamarneh, Sami Khalaf. (2009). History of the Division of Medical, The Project Gutenberg eBook of History of the Division of Medical www.gutenberg.org

Hans K. Biesalski. (2001). Nutraceutical: The Link between Nutrition and Medicine, The University of Hohenheim, Stuttgart, Germany, Marcel Dekker, Inc. New York, NY 10016.

Hilal Zaid, Anwar Rayan, Omar Said \& Bashar Saad, (2010). Cancer Treatment by Greco-Arab and Islamic Herbal Medicine. The Open Nutraceuticals Journal, Arab American University Jenin, Palestine.

Hussain F. Nagamia, MD, FRCS. (2003). Islamic Medicine History and Current Practice, Journal of Islamic History and Islamic Medicine, (JISHIM) Florida, USA, Tampa General Hospital.

Hussaini, M.M and Sakr, A.H., (1983). Islamic Dietary Laws and Practices, Islamic Food and Nutrition Council of America. Bedford Park.IL.

Ibn Qayyim al-Jawziyyah. (1987). Zad al-Ma'ad fi Hady Khayr al-Tbad. 15th Edition, edited by Shu'aib and 'Abd al-Qadir al-Arnaut. Beirut,Muassasat al-Risalah \& Maktabat al-Manar al-Islamiyyah.

Ibn Qayyim al-Jawziyyah. (1998). Medicine of the Prophet. Translated by Johnstone, Penelope. The Islamic Texts Society. Cambridge; U.K 
Ibn Qayyim al-Jawziyyah. (1994). Natural Healing with the Medicine of the Prophet. Translated \& Emended by Muhammad Al-Akili. Philadelphia, U.S.A., Pearl Publishing House.

Ibn Qayyim al-Jawziyyah. (2003). Translated by Jalal Abual Rub (2 $2^{\text {nd }}$ Edition), Darussalam Publisher and Distributors. Riyadh, K.S.A

Ibn Qayyim al-Jawziyyah. (1957). Al-Tibb al-Nabawi. Commentary by Abdul Ghani Abdul Khaliq. Riyadh, K.S.A. Maktabah al-Riyadh al-Hadithah.

Ibn Qayyim al-Jawziyyah. (1990). Al-Tibb al-Nabawi. 14th Edition. Commentary by 'Abd al-Mu'ti Amin Qal'aji. Halab: Dar al-Wa'y.

Ibn Qayyim al-Jawziyyah. (2003). The Prophetic Medicine. Translated by Abd al-Qader Abd al-Azeez. Dar Al-Ghadd Al-Gadeed, Egypt-Al-Mansoura.

Ibn Qayyim al-Jawziyyah. (2014). Perubatan Rasulullah.Translated by Nabilah Abdul Jalil, Al-Hidayah House of Publisher Sdn. Bhd. Batu Caves, Selangor

Ibn Qayyim al-Jawziyyah. (2006) Al-Tibb al-Nabawi. 7th Edition. Commentary by Abdul Ghani Abdul Khaliq.Translated by Abu Umar Basyier Al-Maidani, Jakarta, Griya Ilmu Publisher

Ibn Qayyim al-Jawziyyah, Shams al-Din Abu 'Abd Allah Muhammad bin Abi Bakr al-Zur'i al-Dimashqi. (1987). alFawa'id. (4th Ed.) Beirut, Dar al-Kutub al-'Ilmiyyah.

Ibn Rajab, Abd ar Rahman ibn Ahmad. (1980). Jami’ al Ulum wa al Hikam, fi Syarh Khamsina Hadithan min Jawami' al Kalam, Qaherah, Dar al Hadith.

Ibn Sina, Abu 'Ali al-Husayn, Avicenna's Medicine. (2013). A New Translation of the 11th century Canon, Translated by Mones Abu-Asab, Hakima Amri and Marc.S. Micozzi, Healing Art Press. Toronto, Canada.

Ibnu Kathir. (2003). Tafsir Ibnu Kathir (Abridged) volume 1, (2 ${ }^{\text {nd }}$ Edition), Darussalam Publisher and Distributors. Riyadh, K.S.A.

Ibnu Khaldun, Abdul Rahman Muhammed bin Khaldun. (1987). alMuqaddimah, translated by Rosenthal Franz, The Muqaddimah,Vol 3 (New York: Princeton University Press, 1958)

John D. Keys. (1976). Chinese Herbs: Their Botany Chemistry, Published by Charles E. Tuttle Company, Rutland, Tokyo Japan

Khan, M.Muhsin, The Translation of the Meanings of Sabih Al-Bukhari, The Book of Medicine, Vol 7, no.5684,Darussalam Publishers, Riyadh, Saudi Arabia.

Kumar Pati. (2008). Vitamins, Mineral, Supplement \& Herb Digest. New Editions Publishing, Hayward, California 94544 USA. Pp. 121, 192-193.

L.D Edwards, A.W. Foz, \& P.D Stonier. (2011). Principles and Practice of Pharmaceutical Medicine, (3rd Ed) Blackwell Publishing Ltd. pp.6-7

Lester Packer, \& Klaus Kramer. (2001). Nutraceuticals in Health and Disease Prevention, The Role of Vitamin E in the Emerging Field of Nutraceuticals, University of Southern California School of Pharmacy, Los Angeles, California.By Marcel Dekker, Inc.New York 10016. Pp.27-28

Lim Gim Noi. (2010). The Amazing Black Garlic, (3rd Ed) PCL Publisher Pte.Ltd.Singapore

M.Yunus, A.,W.Chik. W.M., Yusof and Mohamad. M. (2010). The concept of Halalan tayibba and its application in products marketing: A case study at Sabasun HyperRuncit Kuala Terengganu Malaysia. International Journal of Business and Social Science. (1) 3

Malay Heritage Centre, Ilham Alam, Nature Healing in the Malay World. (2015). Published by Malay Heritage Centre, 85 Sultan Gate, Singapore. 
Malaysian Standard for Halal Pharmaceuticals General Guidelines. (2010). (World Halal Research Summit) Kuala Lumpur, Malaysia.

Michael T. Murray \& Joseph Pizzorno. (2012). The Encyclopedia of Natural Medicine (3 ${ }^{\text {rd }}$ Ed.) Published by ATRIA BOOKS - New York, London

Michael Tierra. (1990). The Way of Herbs, published by POCKET BOOKS, New New York.

Mohd Dasuqkhi, Mardiyyah Sahri, Mohd Mahyuddin, Mohd Ashrof and Hanifah Musa. (2012). "Introducing Halalan Tayyiban Concept in Global Industry Practices: An Innovative Attempt" International Proceedings of Economics Development and Research, 66, 44-49.

Muslim. (1996). Sabih Muslim bi Syarh al-Nawawi, Makkah al-Mukarramah, Publisher Maktabah Nazaar Mustafa al-Baaz. Chapter (19), Vol. 4/2797

Nurazmallail Marni. (2012). Medical Epistemology of Ibn Qayyim al-Jawziyyah in Al-Tibb Al-Nabawi, PhD Thesis presented to Senate of Universiti Putra Malaysia.

Nurdeng Deuraseh. (2004). The Emergence and the Objective of Islamic Medicine for the Preservation of Health, al-Shajarah Vol.9 No.1

Nurdeng Deuraseh. (2009). 2nd Ed., Pemikiran Ibn Khaldun \& Relevantasinya dalam Tamadun Kontemporari, Ibn Khaldun on Medical Science pp. 21-52,Kuala Lumpur, Malaysia. Pusat Dialog Peradaban, Universiti Malaya.

Nurdeng Deuraseh. (2009). Preservation of Health in Islamic Law, (1 ${ }^{\text {st }}$ Ed.) Published by IIUM Press, Malaysia.

Paul Pitchford. (2002). Healing with Whole Foods: Asian Traditions and Modern Nutrition, (3rd Ed.) Published by North Atlantic Books, Berkeley, California, USA.

Riaz, Mian N. \& Chaudry, M.M. (2004). Halal Food Production.Published by CRC Press, Boca Raton, London.

Saad Bashar and Said Omar. (2011). Greco-Arab and Islamic Herbal Medicine System, Ethics, Safety, Efficacy and Regulatory Issue.John Wiley \& Sons Publications, Hoboken, New Jersey.

Shibamoto, Takayuki; Kanazawa, Kazuki; Shahidi, Fereidoon et al., eds. (2008). Functional Food and Health. ACS Symposium. pp. 993

Thomas Avery Garran. (2008). Western Herbs According to Traditional Chinese Medicine. Healing Arts Press, Rochester, Vermont.

Wahbah al-Zuhaily. (2001). Tafsir al-Munir, Intel Multimedia and Publication.Petaling Jaya, Selangor.

Wildman, Robert E. (2001). Handbook of Nutraceuticals and Functional Foods (2nd ed.). CRC Series in Modern Nutrition.

Yaseen Ibrahim al-Sheikh. (2004). The Translation of The Meaning of the Fifty Hadith of Jami' al-Ulum WalHikam, Dar Al-Manarah for Publishing \& Distribution El-Mansoura-Egypt, (3 ${ }^{\text {rd }}$ Ed), Vol. 1, pp 65-66

Yusof al-Hajj Ahmad. (2010). Islamic Medicine: the Key to a Better Life. Translation by Nasruddin al-Khattab, (Canada) Edited by Huda Khattab.Darussalam Publisher-Riyadh.

Yusof al-Hajj Ahmad. (2010). The Islamic Guideline on Medicine. Translation by Nasruddin al-Khattab, (Canada) Edited by Huda Khattab.Darussalam Publisher-Riyadh.

Zhari, Ismail. (2011). 'The Halal Index, book on pharmaceuticals, published by Pytorex Press Sdn. Bhd, Kuala Lumpur, Malaysia: Vol. 1, pp xvi , pp 42

Zohary D, Hopf M. (2007). $3^{\text {rd }}$ Ed. Oxford University Press. 